Article

\title{
Development of Convenient System for Detecting Yeast Cell Stress, Including That of Amyloid Beta
}

\author{
Yen Nhi Luu and Ian Macreadie * (iD \\ School of Science, RMIT University, Bundoora, VIC 3083, Australia; s3691025@student.rmit.edu.au \\ * Correspondence: ian.macreadie@rmit.edu.au; Tel.: +61-3-9925-6627
}

Received: 19 June 2018; Accepted: 21 July 2018; Published: 23 July 2018

\begin{abstract}
Background: As a model eukaryote, the study of stress responses in yeast can be employed for studying human health and disease, and the effects of various drugs that may impact health. "Reporting" of stress in yeast has frequently utilised enzymes like $\beta$-galactosidase that require laborious assays for quantitative results. The use of a stress reporter that can be measured quantitatively and with high sensitivity in living cells in a multi-well plate reader is a more desirable approach; (2) Methods: A multi-copy yeast-Escherichia coli shuttle plasmid containing the HSP42 promoter upstream of the mCherry reporter, along with the URA3 selectable marker was constructed and tested; (3) Results: Under certain stress conditions inducing the heat shock response, transformants containing the plasmid produced red fluorescence that could be readily quantitated in a microtitre plate reader. Stresses that produced red fluorescence included exposure to heat shock, copper ions, oligomeric amyloid beta $\left(A \beta_{42}\right)$ and fibrillar $A \beta_{42} ;(4)$ Conclusions: Being able to conveniently and quantitatively monitor stresses in whole live populations of yeast offers great opportunities to screen compounds and conditions that cause stress, as well as conditions that alleviate stress. While freshly prepared oligomeric amyloid beta has previously been shown to exhibit high toxicity, fibrils have been generally considered to be non-toxic or of low toxicity. In this study, fibrillar amyloid beta has also been shown to induce stress.
\end{abstract}

Keywords: heat shock response; heat shock protein; Alzheimer's disease; beta amyloid; yeast

\section{Introduction}

Heat shock proteins (HSPs) are ubiquitously expressed and conserved in both yeast and humans [1]. Low level, constitutive expression of HSPs perform housekeeping functions, assisting in maintenance of proteostasis [2]. HSPs target up to $3 \%$ of the total number of genes in yeast, with some acting as molecular chaperones to assist in binding of and folding of proteins and sequester misfolded polypeptides towards proteolytic pathways, while others are involved in intracellular transport, cell wall maintenance, and oxidative stress mechanisms [3-5]. While HSPs are always present within cells, their expression may be upregulated during the heat shock response (HSR) in response to cellular stress which may include changes in environment, such as elevated temperature [6,7], misfolding or aggregation of proteins [2,3], and reactive oxygen species (ROS) production [8,9]. The HSR is mediated by activity of heat response factors (HRFs) that bind to a 5 bp heat shock element (HSE) in the promotor regions of heat shock genes to initiate transcription $[4,10,11]$.

As a defense mechanism against misfolded and aggregated proteins, HSPs are vital in the response against the toxic Alzheimer's disease (AD) protein $A \beta$. $A \beta$ is present in many forms in an AD-affected brain including monomers, toxic oligomeric intermediates and fibrils. The soluble oligomeric form, particularly $\mathrm{A} \beta_{42}$, produces cytotoxic effects that initiate a cascade of events that contribute to the development of AD due to a higher propensity to aggregate [12-14]. HSPs are found at elevated levels in AD-affected brains, activating microglial phagocytosis and degradation, inhibiting $\mathrm{A} \beta$ formation, 
and slowing down or inhibiting the rate of aggregation, thereby contributing to the clearance of A $\beta[3,5,15,16]$.

$\beta$-galactosidase reporter assays have previously been used for measurement of the HSR towards $A \beta$, in which a yeast HSE was placed upstream of the lac $Z$ gene and $\beta$-galactosidase levels were measured with and without the presence of $A \beta$ [17]. The use of such an assay is somewhat inconvenient in that a preparation of cell lysate is required as well as several commercial reagents.

The aim of this study was to develop an alternative reporter assay for quick screening of the HSR using the mCherry fluorescence reporter, to measure cell stress in whole living cell populations without a need for any reagent addition. Development of this expression system could allow for quick, high throughput screening assays to determine conditions that may cause stress to cells. The demonstration of the use of this system is outlined as follows.

\section{Results}

\subsection{Construction of the $p$ YHSRed1 Plasmid}

The schematic map of the pYHSRed1 plasmid is shown in Figure 1. It has a $2 \mu$ ori for high copy replication in S. cerevisiae. The mCherry reporter is located downstream from the promotor of HSP42, the most abundant cytosolic HSP in yeast for suppression of aggregation [18]. It contains a URA3 gene for selection in S. cerevisiae strains that have a URA3 gene mutation or disruption and therefore require uracil supplementation. For propagation of the plasmid in E. coli it contains the pUC ori and an ampicillin resistance selection marker (encoding $\beta$-lactamase). Transformation of this plasmid into a ura3 mutant $S$. cerevisiae BY4743 strain that requires uracil for growth produces a transformant that no longer requires uracil supplementation. The expression of mCherry expression and red fluorescence should be regulated by the HSP 42 promoter, so the intensity of red fluorescence should indicate the amount of the stress response in the recombinant yeast.

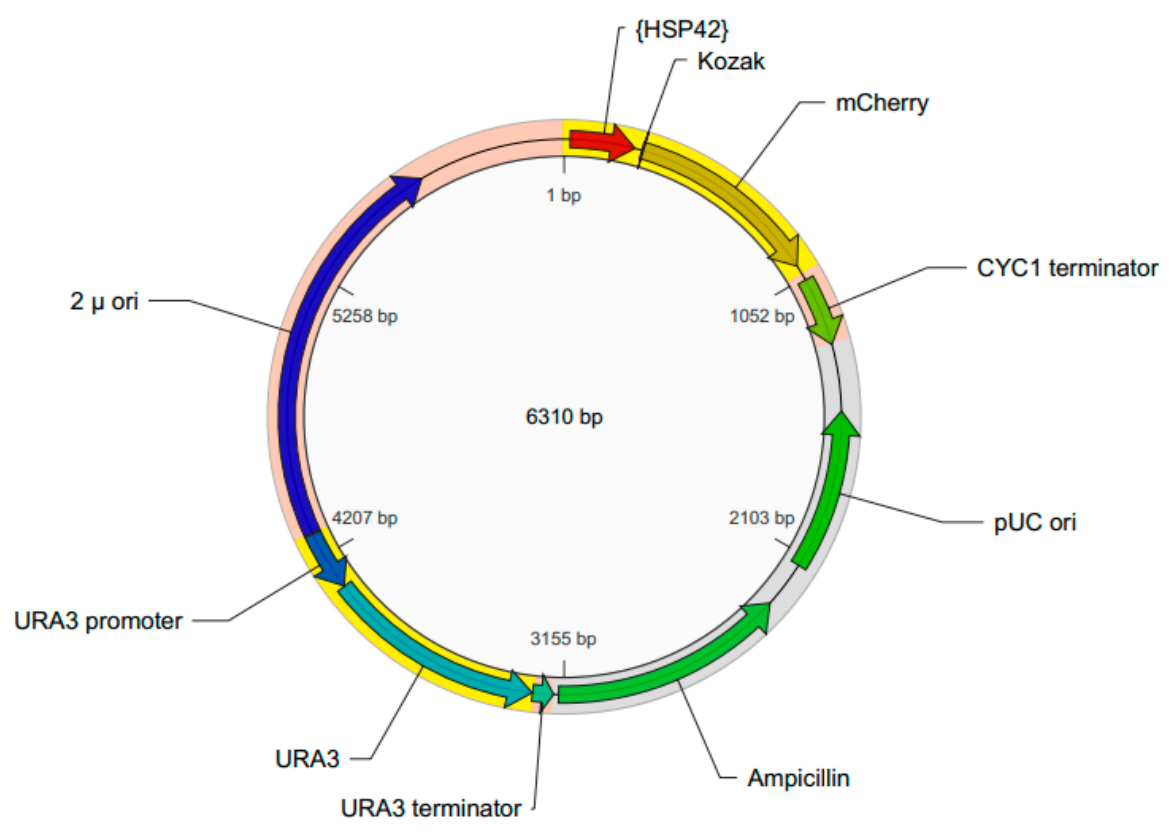

Figure 1. Schematic map of the pYHSRed1 plasmid. 


\subsection{Transformation of Yeast with $p$ YHSRed1 and Basal Expression of mCherry}

To examine the basal levels of red fluorescence afforded by pYHSRed1, a comparison was made between BY4743 and its transformant, BY4743 [pYHSRed1]. BY4743 and BY4743 [pYHSRed1] were grown to exponential phase in liquid minimal media with the appropriate supplementation required by each strain, incubated at $30^{\circ} \mathrm{C}$ for two hours. Transformants had some production of mCherry, as indicated by the increased red fluorescence (Figure 2). This basal expression of mCherry fluorescence in BY4743 [pYHSRed1] was significantly higher $(p<0.05$ for all comparisons at same cell density) than that of the untransformed parental BY4743 strain, indicative of the low level constitutive expression of HSPs in yeast cells when unstressed (Figure 2). The measurement of mCherry fluorescence in cultures of varying cell densities was also analysed to determine how the density of cell cultures affected fluorescence. Fluorescence was proportional to cell density, with cell cultures of larger $\mathrm{OD}_{600}$ readings producing higher mCherry fluorescence. Arbitrary measurements of higher mCherry fluorescence of the parental BY4743 strain were also observed at greater cell densities which may be attributed to high sensitivity of the spectrophotometer. For measurement of fluorescence in successive experiments, cell cultures of $\mathrm{OD}_{600} \geq 0.6$ were utilised.

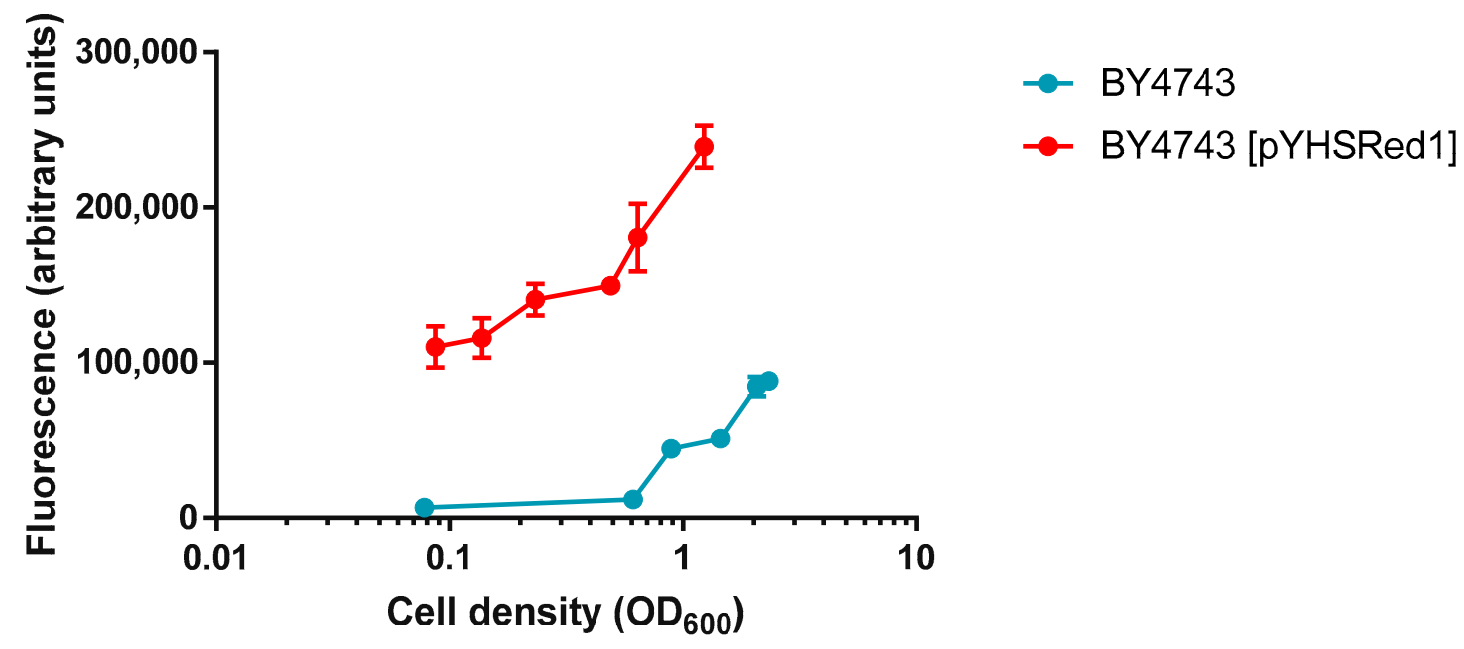

Figure 2. Comparison of basal levels of red fluorescence in BY4743 and BY4743 [pYHSRed1] in cultures of varying cell densities. Mean \pm SEM of Data are shown as triplicate measurements.

\subsection{Increased mCherry Fluorescence in Cells Exposed to Heat Shock and Copper Sulphate}

The mCherry reporter was examined under conditions that induce HSR in cells: elevated temperatures and exposure to metal ions. BY4743 [pYHSRed1] cells were incubated at $42{ }^{\circ} \mathrm{C}$ for two hours, with control cells being incubated at $30^{\circ} \mathrm{C}$. Exposure to $42{ }^{\circ} \mathrm{C}$ resulted in a significant increase in mCherry fluorescence being measured, indicating a significant upregulation in heat shock response genes compared to the control (Figure 3a).

Yeast cells were also exposed to copper sulphate for two hours. Treatment with 0.1 and $0.3 \mathrm{mM}$ $\mathrm{CuSO}_{4}$ did not produce a significant increase in $\mathrm{HSR}$ but cells treated with $0.5 \mathrm{mM} \mathrm{CuSO}_{4}$ produced a significant increase in mCherry fluorescence (Figure $3 b$ ). 


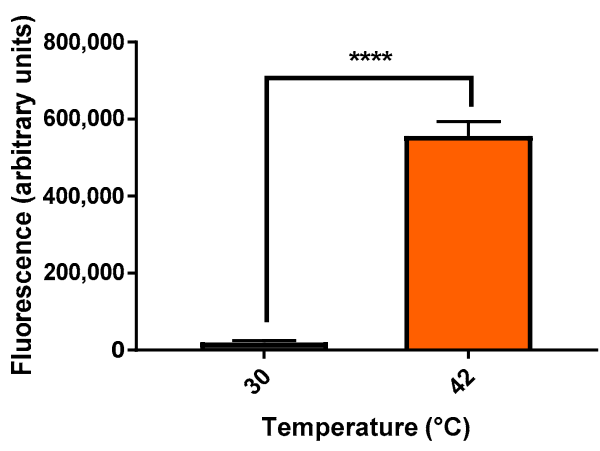

(a)

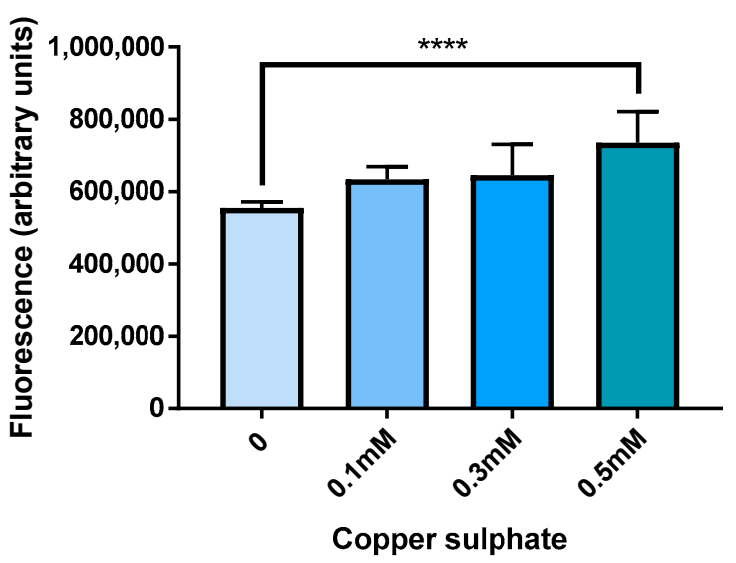

(b)

Figure 3. mCherry fluorescence in BY4743 [pYHSRed1] under heat and copper stress. (a) Heat stress; (b) Stress due to copper sulphate. Data shown as mean \pm SEM of triplicate measurements; **** $p<0.0001$.

\subsection{Stress Induced by Oligomeric and Fibrillar $A \beta_{42}$ Measured by mCherry Fluorescence}

Elevated mCherry levels were measured when yeast cells were treated with both oligomeric and fibrillar $A \beta_{42}$. Cell responses of both exponential and stationary phase cells were measured due to the differing vulnerability of yeast cells in different growth phases to $A \beta_{42}$ toxicity [19].

Oligomeric $A \beta_{42}$ (Figure 4) induced a dose-dependent response in mCherry fluorescence in both stationary and exponential phase cells. A significant increase in mCherry fluorescence was observed in stationary phase yeast cells at $500 \mathrm{nM}$ and $1 \mu \mathrm{M} \mathrm{A} \beta_{42}$, but not with $50 \mathrm{nM} \mathrm{A} \beta_{42}$. A $\beta_{42}$ also induced significant mCherry fluorescence at $50 \mathrm{nM}$ in exponential phase yeast cells, but there was no significant effect at lower levels.

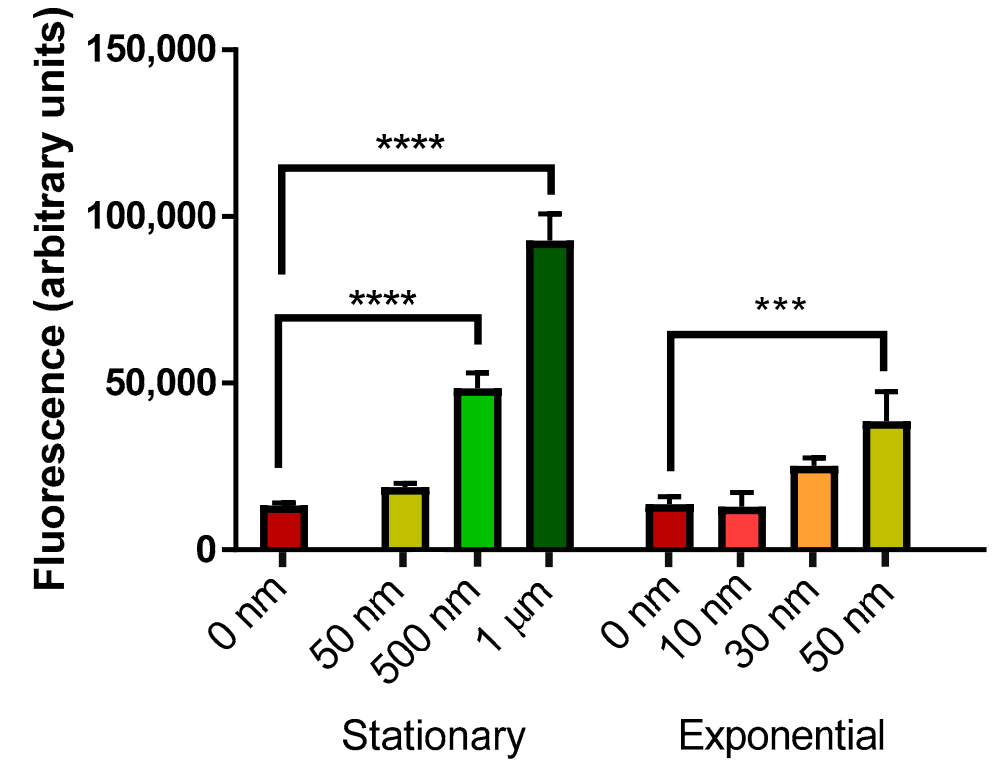

Figure 4. Measurement of mCherry fluorescence of BY4743 [pYHSRed1] cells in stationary and exponential phase growth treated with oligomeric $A \beta_{42}$. Data are shown as mean \pm SEM of triplicate measurements; ${ }^{* * *} p>0.001,{ }^{* * * *} p<0.0001$. 
Fibrillar $A \beta_{42}$ (Figure 5) induced a significant elevation in mCherry fluorescence in stationary phase yeast cells at 50,500 nM and $1 \mu \mathrm{M} \mathrm{A} \beta_{42}$. Levels of 30 and $50 \mathrm{nM} \mathrm{A} \beta_{42}$ also induced significant mCherry fluorescence in exponential phase yeast cells.

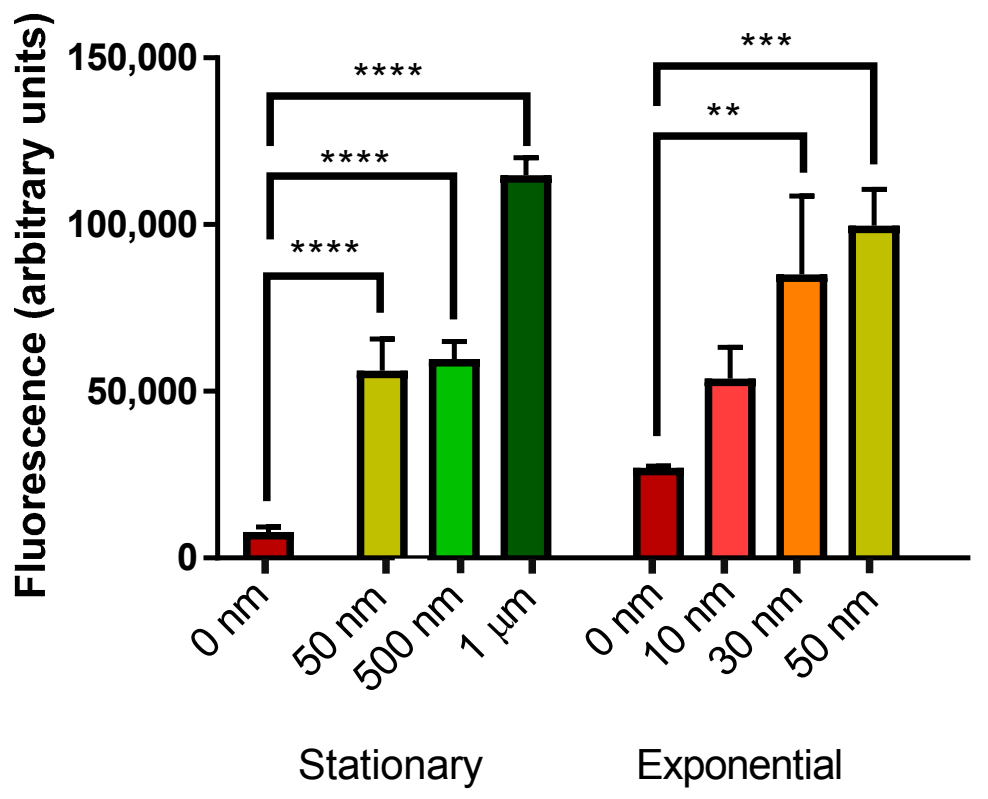

Figure 5. Measurement of mCherry fluorescence of BY4743 [pYHSRed1] cells in stationary and exponential phase growth treated with fibrillar $A \beta_{42}$. Data are shown as mean $\pm \mathrm{SEM}$ of triplicate measurements; ${ }^{* *} p>0.01,{ }^{* * *} p>0.001,{ }^{* * * *} p<0.0001$.

\section{Discussion}

This study aimed to develop a convenient yeast reporter system to measure cell stress correlated with induction of the heat shock response by measuring fluorescence of the mCherry reporter, induced from the HSE of HSP42.

Significant basal mCherry expression of the transformant compared to the wildtype was observed, confirming functionality of pYHSRed1 in transformed yeast. Basal expression of HSPs is expected, as in unstressed conditions, HSPs perform housekeeping functions for proteostasis and regulation of protein quality control $[9,20]$.

mCherry fluorescence in BY4743 [pYHSRed1] transformants after exposure to some known inducers of the heat shock response was measured and significant increases in red fluorescence were observed. For example, there was a significant increase in HSR at $42{ }^{\circ} \mathrm{C}$, as this temperature is a heat shock condition in both mammalian and yeast cells and known to activate HSFs [4,21]. Likewise the HSR is also induced by heavy metal ions and oxidants [22], and at $0.5 \mathrm{mM}$ levels it induced highly significant red mCherry expression. Copper can cause stress as it is a heavy metal and may promote oxidative damage at elevated levels in cells [23].

Oligomeric $A \beta_{42}$ is unstable and toxic, with many studies showing its effect in killing of both yeast cells and neurons [24-26]. Effects of externally supplemented $A \beta_{42}$ cells may differ based on growth stages, as non-quiescent cells are more susceptible to $A \beta_{42}$ toxicity compared to quiescent cells in the first $24 \mathrm{~h}$ of exposure [19]. There is reduced viability of cells exposed to $A \beta_{42}$ oligomers compared to fibrils [24], therefore, lower concentrations of oligomers were applied for treatment. The lower levels of mCherry fluorescence observed compared to fibrillar $\mathrm{A} \beta_{42}$ treatment may be due to this cell killing, reducing the number of cells able to emit fluorescence.

In contrast to oligomers, fibrils are generally viewed as harmless and benign, contributing to the non-toxic plaques found in the brain [14]. Though HSPs can sequester oligomer aggregates, they do not cause significant changes to fibrillar $A \beta$, possibly accumulating on the fibrils due to their inability 
to process them [3,27]. However, insoluble fibrils may induce oxidative stress from fibrillization $[28,29]$. Ladiwala et al. [30] also found fibrils formed at elevated concentrations of $\mathrm{A} \beta$ were toxic. Fibrils prepared with both HFIP and $\mathrm{NH}_{4} \mathrm{OH}$ pretreatment caused toxicity to $S$. cerevisiae [19]. It is possible that, while not cytotoxic like oligomers, the fibrils cause stress and HSR induction in cells through production of ROS and mild cell killing.

Further work needs to be performed to gain greater understanding of this new attribute of fibrillar $\mathrm{A} \beta_{42}$.

\section{Materials and Methods}

\section{1. $p$ YHSRed1, Yeast Strain and Transformation}

The pYHSRed1 was custom designed and produced by VectorBuilder (Cyagen, Santa Clara, CA, USA). It utilises a URA3 multi-copy VectorBuilder plasmid with $238 \mathrm{nt}$ of the HSP42 promoter sequences inserted immediately upstream of the mCherry reporter.

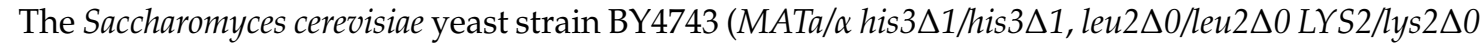
met15 $\Delta 0 /$ MET15 ura3 $\Delta 0 /$ ura3 $\Delta 0$ ) was the host strain used in this study. The plasmid pYHSRed1 was transformed into the host strain as described by Porzoor and Macreadie [31].

\subsection{Yeast Culture Protocol}

Minimal media was used for growth of the BY4743 transformants. The media composition is as follows: Yeast nitrogen base without amino acids $(0.67 \%)$ and dextrose $(2 \%)$. For solidification of media agar $(1.5 \%)$ was added. Supplementation of auxotrophic requirements of BY4743 [pYHSRed1] was performed by adding $20 \mathrm{mg} / \mathrm{L}$ histidine and $30 \mathrm{mg} / \mathrm{L}$ leucine.

Overnight fresh cultures of the transformants were obtained by inoculating one colony into $10 \mathrm{~mL}$ fresh selective minimal media in a $50 \mathrm{~mL}$ tube. The tubes were incubated at $30^{\circ} \mathrm{C}$ at $250 \mathrm{rpm}$. Overnight stationary cultures were further grown to exponential phase by transferring $100 \mu \mathrm{L}$ aliquot to fresh selective minimal media in $15 \mathrm{~mL}$ tubes and incubating at $30{ }^{\circ} \mathrm{C}$ at $250 \mathrm{rpm}$ for a further two hours.

\subsection{Preparation of $A \beta_{42}$}

$\mathrm{A} \beta_{42}$ was pretreated with $\mathrm{NH}_{4} \mathrm{OH}$ as described by [19]. To obtain oligomers, $\mathrm{A} \beta_{42}$ was solubilized in water and used immediately. To obtain fibrils, the $\mathrm{A} \beta_{42}$ was solubilised in water and incubated at $37^{\circ} \mathrm{C}$ for $24 \mathrm{~h}$.

\subsection{Exposure of Yeast Cells to Heat Shock}

Yeast cells were analysed for the effect of exposure to heat shock conditions on mCherry levels. Yeast cells from exponential phase cultures were aliquoted into wells in 96-well microtiter plates. Cells were incubated for a further two hours at 30 and $42{ }^{\circ} \mathrm{C}$.

\subsection{Exposure of Yeast Cells to Copper Ions}

Yeast cells were analysed for the effect of exposure to copper sulphate on mCherry levels. Cells from overnight cultures and exponential phase cultures were suspended in water and then were aliquoted into wells in 96-well microtiter plates. Copper sulphate was added to the diluted cell suspension to required concentrations. The final volume of each well was made up to $200 \mu \mathrm{L}$. The microtiter plate was incubated at $30^{\circ} \mathrm{C}$ for two hours.

\subsection{Effect of Exposure to Oligomeric and Fibrillar A $\beta$ on Yeast Cells}

Yeast cells were analysed for the effect of exposure to fibrillar and oligomeric $A \beta_{42}$ on mCherry levels. Cells from overnight cultures and exponential phase cultures were pelleted by centrifugation and resuspended in water and aliquoted into wells in 96-well microtiter plates. Oligomeric and fibrillar 
$\mathrm{A} \beta_{42}$ were added to the diluted cell suspension to required concentrations. The final volume of each well was made up to $200 \mu \mathrm{L}$. The microtiter plate was incubated at $30^{\circ} \mathrm{C}$ for two hours.

\subsection{Spectrophotometry}

Cell density and mCherry fluorescence was measured with the POLARstar omega microplate reader and analysed with BMG Labtech Mars Data Analysis Software (Ortenberg, Germany). Cell density was measured in Corning 96 Well TC-Treated microplates at $600 \mathrm{~nm}$. mCherry fluorescence was measured from a Nunclon Surface black F96 microtiter plate with top optics using an Ex584 excitation filter and 600-680 emission filter.

Raw data was blank corrected, subtracting the mCherry fluorescence reading of the liquid the cell culture was suspended in, to remove background fluorescence. This figure was then divided by the cell density $\left(\mathrm{OD}_{600}\right)$ reading for the culture.

\section{Conclusions}

The heat shock response is vital in both yeast and human cells for defense against various cell stressors, including misfolded and aggregated proteins associated with neurodegenerative diseases such as Alzheimer's disease. A novel outcome in this study was development of pYHSRed1, a plasmid reporting on stress, especially the HSR, in yeast cells. Coupled with measurement of mCherry fluorescence by a spectrophotometer, the level of stress in live yeast cells may be determined.

Yeast cells containing the pYHSRed1 plasmid were exposed to several conditions known to induce the heat shock response. Elevated temperatures, exposure to metal ions and the subsequent ROS production, and oligomeric and fibrillar $\mathrm{A} \beta_{42}$ all induced significant increases in mCherry production, indicative of the upregulation of transcription of heat shock genes. The significant upregulation of mCherry observed after exposure to fibrillar $A \beta$, considered to be of low or no toxicity, implicates fibrils as a contributor to cellular stress by induction of the HSR.

Transformation of this plasmid into yeast provides an improved method of stress and HSR detection and may be useful for high throughput analysis of therapeutic compounds that may reduce stress caused by $A \beta$. Future studies could also determine the stress of mutant versions of $A \beta$ on yeast cells and to identify therapeutic compounds that may alleviate the effects of other deleterious proteins, biochemicals or cellular states that cause cellular stress.

Author Contributions: Y.N.L. conceived, designed, and performed the experiments and wrote the paper. I.M. conceived, designed, and supervised the study.

Funding: This research received no external funding.

Conflicts of Interest: The authors declare no conflict of interest.

\section{Abbreviations}

$\begin{array}{ll}\text { AD } & \text { Alzheimer's disease } \\ \text { A } \beta & \text { Beta-amyloid } \\ \text { HSE } & \text { Heat shock element } \\ \text { HSF } & \text { Heat shock factor } \\ \text { HSP } & \text { Heat shock protein } \\ \text { HSR } & \text { Heat shock response } \\ \text { ROS } & \text { Reactive oxygen species }\end{array}$

\section{References}

1. Lindquist, S. The heat-shock proteins. Annu. Rev. Genet. 1988, 22, 631-677. [CrossRef] [PubMed]

2. Fink, A.L. Chaperone-mediated protein folding. Physiol. Rev. 1999, 79, 425-449. [CrossRef] [PubMed]

3. Evans, C.G.; Wisen, S.; Gestwicki, J.E. Heat shock proteins 70 and 90 inhibit early stages of amyloid $\beta-(1-42)$ aggregation in vitro. J. Biol. Chem. 2006, 281, 33182-33191. [CrossRef] [PubMed] 
4. Hahn, J.S.; Hu, Z.; Thiele, D.J.; Iyer, V.R. Genome-wide analysis of the biology of stress responses through heat shock transcription factor. Mol. Cell. Biol. 2004, 24, 5249-5256. [CrossRef] [PubMed]

5. Ou, J.R.; Tan, M.S.; Xie, A.M.; Yu, J.T.; Tan, L. Heat shock protein 90 in Alzheimer's disease. BioMed Res. Int. 2014, 2014, 1-8. [CrossRef] [PubMed]

6. Nisamedtinov, I.; Lindsey, G.G.; Karreman, R.; Orumets, K.; Koplimaa, M.; Kevvai, K.; Paalme, T. The response of the yeast Saccharomyces cerevisiae to sudden vs. gradual changes in environmental stress monitored by expression of the stress response protein hsp12p. FEMS Yeast Res. 2008, 8, 829-838. [CrossRef] [PubMed]

7. Sanchez, Y.; Lindquist, S. Hsp104 required for induced thermotolerance. Science 1990, 248, 1112-1115. [CrossRef] [PubMed]

8. Dubey, A.K.; Bharadwaj, P.R.; Varghese, J.N.; Macreadie, I.G. Alzheimer's amyloid- $\beta$ rescues yeast from hydroxide toxicity. J. Alzheimer's Dis. 2009, 18, 31-33. [CrossRef] [PubMed]

9. Kalmar, B.; Greensmith, L. Induction of heat shock proteins for protection against oxidative stress. Adv. Drug Deliv. Rev. 2009, 61, 310-318. [CrossRef] [PubMed]

10. Liu, X.D.; Liu, P.C.; Santoro, N.; Thiele, D.J. Conservation of a stress response: Human heat shock transcription factors functionally substitute for yeast hsf. EMBO J. 1997, 16, 6466-6477. [CrossRef] [PubMed]

11. Wu, C. Heat shock transcription factors: Structure and regulation. Annu. Rev. Cell Dev. Biol. 1995, 11, 441-469. [CrossRef] [PubMed]

12. Thirumalai, D.; Reddy, G.; Straub, J.E. Role of water in protein aggregation and amyloid polymorphism. Acc. Chem. Res. 2012, 45, 83-92. [CrossRef] [PubMed]

13. Hartley, D.M.; Walsh, D.M.; Ye, C.P.; Diehl, T.; Vasquez, S.; Vassilev, P.M.; Teplow, D.B.; Selkoe, D.J. Protofibrillar intermediates of amyloid $\beta$-protein induce acute electrophysiological changes and progressive neurotoxicity in cortical neurons. J. Neurosci. 1999, 19, 8876-8884. [CrossRef] [PubMed]

14. Hardy, J.; Selkoe, D.J. The amyloid hypothesis of Alzheimer's disease: Progress and problems on the road to therapeutics. Science 2002, 297, 353-356. [CrossRef] [PubMed]

15. Kakimura, J.; Kitamura, Y.; Takata, K.; Umeki, M.; Suzuki, S.; Shibagaki, K.; Taniguchi, T.; Nomura, Y.; Smith, M.A.; Gebicke-Haerter, P.J.; et al. Microglial activation and amyloid- $\beta$ clearance induced by exogenous heat-shock proteins. FASEB J. 2002, 16, 601-603. [CrossRef] [PubMed]

16. Smith, R.C.; Rosen, K.M.; Pola, R.; Magrane, J. Stress proteins in Alzheimer's disease. Int. J. Hyperther. 2005, 21, 421-431. [CrossRef] [PubMed]

17. Caine, J.; Sankovich, S.; Antony, H.; Waddington, L.; Macreadie, P.; Varghese, J.; Macreadie, I. Alzheimer's $\mathrm{A} \beta$ fused to green fluorescent protein induces growth stress and a heat shock response. FEMS Yeast Res. 2007, 7, 1230-1236. [CrossRef] [PubMed]

18. Haslbeck, M.; Braun, N.; Stromer, T.; Richter, B.; Model, N.; Weinkauf, S.; Buchner, J. Hsp42 is the general small heat shock protein in the cytosol of Saccharomyces cerevisiae. EMBO J. 2004, 23, 638-649. [CrossRef] [PubMed]

19. Porzoor, A.; Caine, J.M.; Macreadie, I.G. Pretreatment of chemically-synthesized A $\beta_{42}$ affects its biological activity in yeast. Prion 2014, 8, 404-410. [CrossRef] [PubMed]

20. Jakobsen, B.K.; Pelham, H.R. Constitutive binding of yeast heat shock factor to DNA in vivo. Mol. Cell. Biol. 1988, 8, 5040-5042. [CrossRef] [PubMed]

21. Mager, W.H.; De Kruijff, A.J. Stress-induced transcriptional activation. Microbiol. Rev. 1995, 59, 506-531. [PubMed]

22. Ananthan, J.; Goldberg, A.L.; Voellmy, R. Abnormal proteins serve as eukaryotic stress signals and trigger the activation of heat shock genes. Science 1986, 232, 522-524. [CrossRef] [PubMed]

23. Avery, S.V.; Howlett, N.G.; Radice, S. Copper toxicity towards Saccharomyces cerevisiae: Dependence on plasma membrane fatty acid composition. Appl. Environ. Microbiol. 1996, 62, 3960-3966. [PubMed]

24. Bharadwaj, P.; Waddington, L.; Varghese, J.; Macreadie, I.G. A new method to measure cellular toxicity of non-fibrillar and fibrillar Alzheimer's A $\beta$ using yeast. J. Alzheimer's Dis. 2008, 13, 147-150. [CrossRef]

25. Dahlgren, K.N.; Manelli, A.M.; Stine, W.B., Jr.; Baker, L.K.; Krafft, G.A.; LaDu, M.J. Oligomeric and fibrillar species of amyloid-ß peptides differentially affect neuronal viability. J. Biol. Chem. 2002, 277, 32046-32053. [CrossRef] [PubMed]

26. Stefani, M. Biochemical and biophysical features of both oligomer/fibril and cell membrane in amyloid cytotoxicity. FEBS J. 2010, 277, 4602-4613. [CrossRef] [PubMed] 
27. Lee, S.; Carson, K.; Rice-Ficht, A.; Good, T. Small heat shock proteins differentially affect A $\beta$ aggregation and toxicity. Biochem. Biophys. Res. Commun. 2006, 347, 527-533. [CrossRef] [PubMed]

28. Chauhan, V.; Chauhan, A. Oxidative stress in Alzheimer's disease. Pathophysiology 2006, 13, $195-208$. [CrossRef] [PubMed]

29. Varadarajan, S.; Yatin, S.; Aksenova, M.; Butterfield, D.A. Alzheimer's amyloid $\beta$-peptide-associated free radical oxidative stress and neurotoxicity. J. Struct. Biol. 2000, 130, 184-208. [CrossRef] [PubMed]

30. Ladiwala, A.R.; Litt, J.; Kane, R.S.; Aucoin, D.S.; Smith, S.O.; Ranjan, S.; Davis, J.; Van Nostrand, W.E.; Tessier, P.M. Conformational differences between two amyloid $\beta$ oligomers of similar size and dissimilar toxicity. J. Biol. Chem. 2012, 287, 24765-24773. [CrossRef] [PubMed]

31. Porzoor, A.; Macreadie, I. Yeast as a model for studies on abeta aggregation toxicity in Alzheimer's disease, autophagic responses, and drug screening. Methods Mol. Biol. 2016, 1303, 217-226. [PubMed]

2018 by the authors. Licensee MDPI, Basel, Switzerland. This article is an open access article distributed under the terms and conditions of the Creative Commons Attribution (CC BY) license (http:/ / creativecommons.org/licenses/by/4.0/). 